\title{
Quantitative Reasoning Middle-School Students in Problem Based Learning
}

\author{
Muhhammad Muzaini $^{{ }^{*}} \quad$ Dwi Juniati $^{2} \quad$ Tatag Y.E Siswono ${ }^{2}$ \\ 1.Department of Mathematics Education, Universitas Cokroaminoto Palopo, Indonesia. Jl. Latammacelling No. \\ 19, Sulawesi Selatan, Indonesia \\ 2.Department of Mathematics Education, Universitas Negeri Surabaya, Indonesia. J1. Ketintang, Ketintang, Kec. \\ Gayungan, Surabaya, Jawa Timur. 60231
}

\begin{abstract}
This study was conducted with the aim to notice the effect of Problem Based Learning in improving 8th grade Middle-School students' quantitative reasoning by employing measuring tools of an quantitative reasoning test and observation sheet, which were developed, was distributed to 50 experimental group students and 45 control group students, which makes 95 learners in total. This study was accompanied experimental by pre-test - posttest control group design. These participant are studying at 8.1th grade as the experimental group and 8.2th grade as the control group from a Middle-School 1 Pangkajene. Problem Based Learning was implemented on experimental group while Control group was implemented to current Curriculum. The result of conducted experimental group, it was be discovered that quantitative reasoning test and observation sheet of experimental group students are better than control group students. Furthermore, based on the results of the quantitative reasoning test, $86.1 \%$ of students obtained N-Gain more than or equal to 0.7 . Therefore, it is possible to say that Problem Based Learning is more efficient than the learning in control group. So that quantitative reasoning test and observation sheet may be recommended for future studies.
\end{abstract}

Keywords: Problem Based Learning, Quantitative Reasoning, Middle-School 1 Pangkajene

DOI: $10.7176 / \mathrm{JEP} / 10-26-10$

Publication date:September $30^{\text {th }} 2019$

\section{Introduction}

Reasoning is a thinking process that attempts to link facts that are known to lead to conclusions (Gorys, 2007). Reasoning is the process of thinking in the process of drawing conclusions (Sumarmo, 2013). Broadly speaking, reasoning is divided into two namely inductive and deductive. Drawing conclusions based on a number of cases or examples is called induction while drawing conclusions based on agreed rules is called deduction (Sumarmo, 1987). Reasoning is one aspect of the goals of middle-school mathematics. This is evident in the Minister of National Education Regulation No. 22 of 2006 (Ministry of Education and Culture, 2006) which states that secondary school mathematics aims to have students the ability to use reasoning on patterns and traits, making mathematical manipulations in making generalizations, compiling evidence or explaining mathematical ideas and statements, solving problems that include the ability to understand problems, designing mathematical models, completing models and interpreting solutions obtained. The explanation states that the purpose of teaching mathematics in middle-school is to develop the ability to use reasoning. So that Mathematics plays an important role in training students to reason in drawing conclusions to solve problems, both problems in mathematics and problems in daily life-day.

Quantitative reasoning is one of the important mental processes for students in mathematics (Thompson, 1993; Ellis, 2007a, 2007b, 2011; Carlson, and Oehrtman, 2013; Hackenberg, 2010a, 2010b; Moore, Weber et al. 2014; Ramful and Ho, 2015). Quantitative Reasoning is the ability developed in mathematics learning to analyze quantitative information and to determine the skills and procedures that can be applied to a particular problem to arrive at a solution. The goals of mathematics education include discussing quantitative reasoning as an ability that must be developed in all students (NCTM, 2000; MAA, 2003; Howe, 1998; AMATYC, 1995). Sroyer (2013) defines quantitative reasoning as a reason that emphasizes drawing conclusions based on quantitative data or information. Furthermore, according to Dweyer et al, (2003) states that quantitative reasoning needs to be developed in mathematics learning to develop students' ability to analyze quantitative information and determine the skills and procedures that can be applied to certain problems to arrive at a solution or conclusion. Carroll (1993) states that quantitative reasoning already exists in children aged five years to adulthood. He concluded that there were three main reasoning abilities: sequential (deductive), inductive, and quantitative. There are 4 types of questions to measure QR, namely: quantitative comparison, multiple choice (multiplechoice-select one), multiple choice (multiplechoice select one or more), and enter answers in the box (numeric entry) (ETS, 2010).

The results of the study stated positively that quantitative reasoning has a good effect on students because it will be able to make students understand and make good arguments supported by quantitative facts and can communicate these arguments clearly in various representations (Madison, 2003; Kabael \& Tangul, 2016). Revealed that the use of quantitative reasoning would increase the level of students' ability to understand and 
solve problems in daily life, the amount of reason or level of mastery of numbers, mental calculation would be better or calculations without using tools but using the brain, and be able to assess the solution of a problem (Karim, 2007). Furthermore, quantitative reasoning has a very important value in learning mathematics in schools (Madison, 2003; Kabael et al. 2016). Recent research results emphasize that mathematics teachers have an important role in developing students' quantitative reasoning (Tangul, 2016). Ellis (2007) states that to improve students' quantitative reasoning in a learning environment is highly dependent on mathematics teachers who are able to use well-structured questions, such as asking the right questions, directing students to carefully consider quantitative relationships in problem situations. confronted and think quantitatively.

Based on the description above, learning can be applied to improve students' quantitative reasoning, namely Problem Based Learning (PBL). Problem Based Learning is appropriate and appropriate for students because it uses contextual problems as a starting point for learning with well structured questions, such as asking the right questions, directing students to carefully consider quantitative relationships in problem situations and think quantitatively. The impact is to increase the level of students' ability to understand and solve problems in daily life-day.

\section{Literature review}

\subsection{Problem Based Learning}

Problem Based Learning (PBL) is one of the learning models that uses contextual problems as a context for students to learn about problem solving reasoning (Arends, 2008). The selection of PBL models is also in accordance with the objectives of mathematics learning that focus on ways of thinking or reasoning, developing creative activities, developing problem solving skills and communicating ideas. Problem Based Learning (PBL) is one of the student-centered approaches and has been considered by a number of higher education institutions in many parts of the world as a delivery method (Awang \& Ramly, 2008). The Problem Based Learning model transforms students from passive recipients of information into independent, active and problem-solving learners, and it shifts the emphasis of educational programs from teaching to learning (Akınoğlu \& Tandoğan, 2007). PBL learning requires students to ask questions and express opinions, find relevant information from hidden sources to find different (alternative) ways to get solutions, and find the most effective way to solve the problem. Based on the syntax of Problem Based Learning (PBL), that this teaching and learning model requires students to be more active in reasoning in solving problems. Problem Based Learning that involves students in their own investigations, allows students to interpret and explain real-world phenomena and build their understanding of these phenomena. Following under syntax Problem Based Learning (PBL) (Arends, 2012).

Table 1: Phase Problem Based Learning (PBL)

\begin{tabular}{|c|c|}
\hline Phases & Teacher Actvities \\
\hline $\begin{array}{l}\text { Phase } 1 \\
\text { Student orientation to problems }\end{array}$ & $\begin{array}{l}\text { Explain the purpose of learning } \\
\text { Explain the logistics required } \\
\text { Motivate students to be actively involved in solving selected problems }\end{array}$ \\
\hline $\begin{array}{l}\text { Phase } 2 \\
\text { Organizing students }\end{array}$ & $>$ Helps students define and organize learning tasks related to problems \\
\hline $\begin{array}{l}\text { Phase } 3 \\
\text { Individual and group research } \\
\text { guides }\end{array}$ & $\begin{array}{l}\text { Encourage students to gather information accordingly } \\
\text { Encourage students to conduct experiments for explanation and problem } \\
\text { solving }\end{array}$ \\
\hline $\begin{array}{l}\text { Phase } 4 \\
\text { Develop and present work } \\
\text { results }\end{array}$ & $\begin{array}{l}\text { Assist students in planning and preparing appropriate work results such } \\
\text { as reports, models, and sharing assignments with friends. }\end{array}$ \\
\hline $\begin{array}{l}\text { Phase } 5 \\
\text { Analyze and evaluate the } \\
\text { process problem solving }\end{array}$ & $\begin{array}{l}\text { Evaluate learning outcomes about the material that has been learned / } \\
\text { request group presentations from student work. }\end{array}$ \\
\hline
\end{tabular}

Based on such proposal, This study aims to notice at the effect of Problem Based Learning in improving quantitative reasoning for secondary school students 8 , the questions below that need to be answered.

- Is there significant differences between students 'pre-test and post-test scores which indicating an effect of teaching on students' quantitative reasoning?

- Is there an increase between students 'pre-test and post-test that indicating an effect of instruction on students' quantitative reasoning?

\section{Methods}

This study used experimental research with the design of two-groups of pretest-posttest design. The study population was all 8th grade students of Middle School 1 Pangkajene. The Sample of this study consists of 8.1th grade and 8.2th grade from the population sampling 8th grade with a total of 95 students. The experimental grade taught with the problem based learning is 8.1 th grade which consists of 28 female students and 22 male 
students, while the control grade taught with conventional learning is 8.2 th grade consists of 25 female students and 20 male students.

Data collection tools developed in this study uses a quantitative reasoning ability test sheet (TKPK) and an observation sheet. The TKPK test instrument consisted of 5 questions on the topic of prism. The observation sheet consists of observing teacher activities and student activities to see student activities during the lesson. Before conducting the research, the TKPK test instrument and observation sheet were validated by experts consisting of 3 lecturers and 1 mathematics teacher. after being declared valid with a validity coefficient of 0.85 and a reliability coefficient of 0.74 .

Furthermore, the TKPK description test items were tested to students to get the level of validity and the level of reliability of the instruments to be used, the TKPK items were tested outside the research subject. To measure the validity of an item, you can use the product moment correlation formula (Malhotra at al. 2007) below.

$$
\mathrm{r}_{\mathrm{xy}}=\frac{n \sum_{i=1}^{n} x_{i j} y_{i}-\left(\sum_{i=1}^{n} x_{i j} \sum_{i=1}^{n} y_{i}\right)}{\sqrt{\left\{n \sum_{i=1}^{n} x_{i j}^{2}-\left(\sum_{i=1}^{n} x_{i j}\right)^{2}\right\}\left\{\left\{\sum_{i=1}^{n} y_{i}^{2}-\left(\sum_{i=1}^{n} y_{i}\right)^{2}\right\}\right.}}
$$

Then, to calculate the reliability coefficient the Alpha-Cronbach test item (Urbina, 2004) is used as follows:

$$
\mathrm{r}_{11}=\left(\frac{n}{n-1}\right)\left(1-\frac{\sum_{i=1}^{n} \sigma_{i}^{2}}{\sigma_{t}^{2}}\right)
$$

Data Analysis pre-test results of TKPK were compared with non-parametric Mann-Whitney U test. As a result of the comparison, there was no significant difference between the scores of experimental and control groups in terms of TKPK pre-test scores. Since TKPK post-test scores of experimental and control groups provide parametric testing propositions, were compared with independent t-test.

Table 2: Mann-Whitney U test results of TKPK pre-test scores.

\begin{tabular}{|c|l|c|c|c|c|c|}
\hline Test & \multicolumn{1}{|c|}{ Group } & $\mathrm{N}$ & Average & Total & $\mathrm{U}$ & $\mathrm{P}$ \\
\hline \multirow{2}{*}{ TKPK } & Experimental & 50 & 55.53 & 2776.5 & \multirow{2}{*}{472.05} & \multirow{2}{*}{0.205} \\
\cline { 2 - 5 } & Control & 45 & 51.21 & 2304.45 & & \\
\hline
\end{tabular}

Hypothesis criteria: hypothesis $\left(\mathrm{H}_{0}\right)$ accepted if: $\mathrm{T}_{\text {coun }} \mathrm{t}>\mathrm{T}_{\text {table }}$ and hypothesis $\left(\mathrm{H}_{1}\right)$ rejected. The research hypothesis is as follows:

- $\mathrm{H}_{0}$ : There is not significant differences between students 'pre-test and post-test scores which indicating an effect of teaching on students' quantitative reasoning.

- $\mathrm{H}_{1}$ : There is significant differences between students 'pre-test and post-test scores which indicating an effect of teaching on students' quantitative reasoning.

Furthermore, to determining the level of improvement in the pretest (TKPK) and posttest (TKPK) results, the calculation results above are further categorized and matched with interpretation based on the formulas and criteria in Table 3 below.

$$
\mathrm{N}-\text { Gain }=\frac{\text { Posttest Score- } \text { Pretest Score }}{\text { Maksimum Score-Pretest Score }}
$$

Table 3: N-Gain Value Criteria

\begin{tabular}{|c|c|}
\hline N-Gain & Criteria \\
\hline N-Gain $\geq 0,70$ & High \\
\hline $0,30 \leq \mathrm{N}-$ Gain $<0,70$ & Medium \\
\hline N-Gain $\leq 0,30$ & Low \\
\hline
\end{tabular}

The average N-Gain value obtained by students in the experimental grade is $86.1 \%$ more than or equal to 0.7 . It can be said that, while in the control grade that is $65 \%$ more than or equal to 0.3 .

Table 4: N-Gain results of TKPK post-test

\begin{tabular}{|c|c|}
\hline N-Gain & Criteria \\
\hline N-Gain $\geq 0,70$ & $86.1 \%$ \\
\hline $0,30 \leq$ N-Gain $<0,70$ & $65 \%$ \\
\hline
\end{tabular}

\section{Findings}

The process of conducting study begins with giving TKPK tests to both classes to see the level of students' initial quantitative reasoning ability. After applying a problem based learning, a test is given to see the improvement of students' quantitative reasoning ability. The control grade and the experimental grade are given different learning treatments. Table 5 shows results TKPK to reveal if designed instruction created a significant difference on students' quantitative reasoning in terms of pre-test and post-tes scores. 
Table 5: Results of TKPK scores

\begin{tabular}{|c|l|c|c|c|}
\hline Test & Class & Number of Subject & Highest Score & Lowest Score \\
\hline \multirow{2}{*}{ Pre-Test } & Experiment & 50 & 70 & 45 \\
\cline { 2 - 5 } & Control & 45 & 65 & 40 \\
\hline \multirow{2}{*}{ Post-Test } & Experiment & 50 & 100 & 75 \\
\cline { 2 - 5 } & Control & 45 & 80 & 50 \\
\hline
\end{tabular}

Based on Table 5 above, it was found that the students quantitative reasoning using Problem Based Learning (PBL) showed better results by looking at the average obtained by students in the experimental grade and the control grade.

Then, the initial analysis is carried out normality and homogeneity test with the purpose to find out data from two groups with normal distribution and homogeneous data obtained. Next, the hypothesis test is performed to show the $\mathrm{T}_{\text {value }}$ calculated from the pre-test and post-test data. Based on statistical results, $\mathrm{T}_{\text {count }}=$ 15,565 and $T_{\text {table }}(\mathrm{N}-2)=1,985$. So that $\mathrm{T}_{\text {count }}>\mathrm{T}_{\text {table }}$ is obtained, based on this hypothesis (H1) accepted and (H0) rejected, so it can be concluded that the students' quantitative reasoning using Problem Based Learning (PBL) in experiments grade increases and is better than students who get treatment with conventional learning in the control grade. As well as seen from the posttest value of students that fulfills the number that gets a value above the Classical Completion Criteria. Learning completeness achieved by students in classical is more than $75 \%$.

Based on observations during learning on eksperiment grade, the results indicate that the teacher's activities in learning meet good criteria at each stage in the Problem Based Learning (PBL). Then, student activities that meet active criteria in learning are marked by the ideal time set in the lesson plan to meet the time limit for effectiveness of tolerance and provide a positive response to mathematics learning in class. Early learning students are given contextual problems, so students will understand quantitative information in the problem; link between the amount contained in the situation; look for the same relationship between two or more numbers; look for procedures to detect interpersonal relationships; detect patterns in certain situations; repeat the pattern to get the general shape; and applies to new situations. Thus students will build their own knowledge by connecting prior knowledge with their current knowledge to produce conclusions from the material that has been taught. Contextual problems are facilitated by the teacher in the learning process, so students are enthusiastic because they can solve problems related to students' daily lives, and students can apply their mathematical skills in their daily lives. In addition, the problem presented develops the ability of students to analyze quantitative information and determine the skills and procedures that can be applied to a particular problem to arrive at a solution or conclusion.

In mathematics learning takes place, student responses meet the positive criteria for learning used, because students are given contextual problems to understand the quantitative information that is in the problem; link between the amount contained in the situation; look for the same relationship between two or more numbers; look for procedures to detect relationships between numbers; detect patterns in certain situations; repeat the pattern to get the general shape; and applies to new situations. So, students are motivated to build, reason and develop their own knowledge skills with better teacher guidance, so that quantitative reasoning and their learning experiences will be more meaningful and lasting in the long run.

In learning activities, observers observe teacher activities and student activities in learning using Problem Based Learning (PBL). Based on observations made by observers, the following is a description of the learning process obtained. The stage of treatment or implementation of learning is carried out with several meetings. Each meeting lasts 90 minutes with estimated learning time from the initial activity to closing. The material discussed in each meeting in this study was prism material. For each meeting, students are given contextual problems related to the prism material in this case the surface area and volume of prisms that will be discussed with student group friends. Initial learning activities, the teacher arranges classes for learning activities and conveys the objectives of the material to be studied. The teacher forms a group based on gender and the level of ability of students with the aim that students will hold group discussions and solve problems that have been delivered by the teacher.

When the material discussion took place, several students in each group asked the teacher questions about the contextual problems they discussed. In the learning process the teacher does not directly answer questions from students, but the teacher only repeats the material and provides reasonable guidance, so students can find their own answers. In addition, the teacher also motivates students to explore and build mathematical skills, so that students involved in learning activities understand mathematics in general. After the group discussion is over, the teacher asks one representative from each group to present the results of their discussion and write it on the board. After the group presents and presents the results of the discussion, the teacher checks whether the results are in accordance with what is expected in the learning objectives. Then the teacher will explain further to confirm the results of the discussion from each group. At the end of the lesson, the teacher and students analyze and evaluate the problem solving process. 


\section{Discussion and Conclusion}

This research was conducted by several researchers before using Problem Based Learning (PBL). In general, the results of this study can improve students' quantitative reasoning. In this study shows that the average quantitative reasoning of students who use Problem Based Learning (PBL) increases and is better than the control class. This result occurs because the learning process using Problem Based Learning (PBL) encourages and motivates students to find their own answers to a given problem. By using Problem Based Learning (PBL) that is connected with the mathematical concept itself, other scientific concepts and other daily lives, students can develop students' ability to analyze quantitative information and determine the skills and procedures that can be applied to a particular problem to arrive at a solution or conclusions (Dweyer et al, 2003).

Learning theory is a guide for teachers to help students develop their cognitive, social, and spiritual. The development so far with Based Learning has always been based on 4 theories namely Piaget's theory, Vygotsky's theory, Bruner's theory and Ausubel's theory (Slavin, 2006). In accordance with learning theory, learning and thinking basically change and develop cognitive structures. In his theory Piaget argues that a person's cognitive structure occurs because of the process of adaptation. Adaptation is the process of adjusting the scheme in response to the environment through two processes of assimilation and accommodation.

The learning process with PBL is very closely related to theory, it is based on Piaget's theory, because Problem Based Learning (PBL) focuses on how students think and reason, not focus on student achievement outcomes. Furthermore, students who are given contextual problems will be given the opportunity to define and organize learning tasks related to the problem, Students gather quantitative information accordingly, students to conduct experiments for explanation and problem solving (Arends, 2012). One important theory in the psychology of student development is Vygotsky's theory. This theory emphasizes the nature of sociocultural learning. In accordance with Vygotsky's opinion that learning occurs when children work or learn in completing tasks that have not been studied before but these tasks are still in the zone of proximal development. Universally, higher mental functions appear in conversation or cooperation between individuals, before higher mental functions are absorbed into individuals according to Vygotsky (Slavin, 2006).

It contains two main effects based on Vygotsky's theory of learning science. First, the conditions in the classroom are designed with cooperative learning, so that with these groups students will be able to interact with group friends to solve problems that are classified as difficult and produce effective problem solving strategies in each of their proximal development zones. Second, this theory also applies to those who teach by emphasizing providing assistance or guidance so that students become increasingly responsible for their own learning (Slavin, 2006). This theory is in accordance with Problem Based Learning (PBL), which is a contextual problem that is presented to students in understanding and solving it designed in groups, and students in planning and preparing appropriate work outcomes such as reports, models, and sharing assignments with friends. With this model each student will feel confident and responsible for their own knowledge gained from the results of the discussion and can improve students' quantitative reasoning.

Learning mathematics is learning about the concepts and structures of mathematics found in the material studied and for discovering the relationship between the concepts and mathematical structures of Bruner (Hudoyo, 1988). Through these concepts and structures, so that a material will be comprehensively understood. In addition, student knowledge is easier to remember and last longer if the material being studied has a structured pattern. Furthermore, in this theory students' cognitive development is developed through three stages, namely the active stage in which students learn to use concrete objects directly so that they can manipulate concrete objects, iconic stages that do not use concrete objects but use concrete objects, symbolic stages where students learn by manipulating direct symbols that are not related to the object. So, it can be concluded that Bruner's theory is in accordance with RME, the suitability of first guided rediscovery and progressive mathematics, and conformity with the second principle, didactic phenomenology, conformity with the characteristics of the first RME is to use context, third is student contributions and fourth is interactivity.

Learning mathematics is learning about mathematical concepts and structures found in the material being studied and to find the relationship between Bruner's concepts and mathematical structures (Hudoyo, 1988). Through this concept and structure, so that a material will be comprehensively understood. In addition, student knowledge is easier to remember and last longer if the material being studied has a structured pattern. Furthermore, in this theory students' cognitive development is developed through three stages, namely the active stage where students learn to use concrete objects directly so that they can manipulate concrete objects, the iconic stage that does not use concrete objects but uses concrete, symbolic objects., the stage where students learn by manipulating symbols directly that are not related to objects. So, it can be concluded that Bruner's theory is in accordance with PBL, the suitability of students' orientation to the problem, and the suitability of student organizing, suitability with individual and group research guidelines, third is to develop and present work results, and suitability in analyzing and evaluating the problem solving process.

Based on the analysis of the results of the above data obtained from the pre-test, post-test, and observation in the experimental class and the control class. The conclusions in this study conducted at SMP Negeri 1 
Pangkajene are presented below:

a) The ability of students' quantitative reasoning to use Problem Based Learning (PBL) in the experimental grade increased significantly and was better than the control grade.

b) The observations, the activities of the teacher are done well and the students' activities show that they are actively characterized by students who are more enthusiastic in learning mathematics using the Problem Based Learning (PBL).

c) Based on the results of students' quantitative reasoning tests, $86.1 \%$ of students obtained an N-gain more than or equal to 0.7. Therefore, it is possible to say that Problem Based Learning is more efficient than learning in the control grade.

The conclusion obtained above is that learning mathematics using Problem Based Learning (PBL) can improve quantitative reasoning students and teachers must master learning models such as Problem Based Learning (PBL) so that the learning process in the classroom becomes more active, diverse, and learning will be meaningful so that students' knowledge will last a long time and will improve student learning outcomes (Quantitative Reasoning) for the better.

\section{Suggestions}

Until now, teaching with Problem Based Learning (PBL) has been published in the 2013 curriculum which facilitates this country, the importance of Problem Based Learning (PBL) has been published so that students can learn mathematics in the context of dayliday life, so as to improve students' quantitative reasoning. The application of this model has been carried out in elementary schools and middle-schools and provides an excellent reference on Problem Based Learning (PBL). This program is a program to improve the quality of education and inquiry-based. In general, from several research results, Problem Based Learning (PBL) has a very important effect on the use of quantitative reasoning, student thinking skills and building student knowledge. However, teaching Problem Based Learning (PBL) for learning mathematics is very different from teaching in general. Because this model requires teachers who are professional and competent in teaching mathematics. So, the teacher must spend extra time and work hard to teach students about mathematics in a real world context. This model has a slight disadvantage because in the learning process students are accustomed to getting information in advance, so students are still having trouble finding their own answers in orientation and organizing problems, so it takes a long time for students who have low ability.

\section{References}

Akınoğlu, O, \& Tandoğan, R. O. (2007). The Effects of Problem-Based Active Learning in Science Education on Students' Academic Achievement, Attitude and Concept Learning. Eurasia Journal of Mathematics, Science \& Technology Education, 3(1), 2007, 71-81. doi: 10.12973/ejmste/75375.

American Mathematical Association of Two-Years Colleges (AMATYC). (1995). Crossroads in Mathematics: Standards For Introductory College Mathematics Before Calculus. https://eric.ed.gov/?id=ED386231

Arends, R. I. (2012), Learning to Teach ninth edition. (New York: McGraw-Hill).

Awang, H., \& Ramly, I. (2008). Creative Thinking Skill Approach Through Problem-Based Learning: Pedagogy and Practice in the Engineering Classroom. International Journal of Human and Social Sciences 3:1, 60-65. doi=10.1.1.306.7430.

Carlson, M. P, Oehrtman, M., \& Moore, K. (2013). Precalculus Pathways To Calculus Student Workbook.

Carroll, J. B. (1993). Human Cognitive Abilities: A Survey of Factor-Analytic Studies. (Cambridge, England: Cambridge University Press)

Dwyer, C. A., Gallagher, A., Levin, J., \& Morley, M. E. (2003). What Is Quantitative Reasoning? Defining The Construct For Assessment Purposes. (ETS Research Report Series). http://dx.doi.org/10.1002/j.23338504.2003.tb01922.x.

Ellis, A. B. (2007). A taxonomy for categorizing generalizations: Generalizing actions and reflection generalizations. The Journal of the Learning Sciences, 16(2), 221-262. doi: 10.1080/10508400701193705.

Ellis, A. B. (2007). Connections Between Generalizing And Justifying: Students' Reasoning With Linear Relationships. Journal for Research in Mathematics Education, 16(3), 194-229. doi: 10.2307/30034866.

Gorys. K. (2007). Argumentation and Narration. (Jakarta: PT Gramedia).

Hackenberg, A. J. (2010). Mathematical Caring Relations İn Action. Journal for Research in Mathematics Education, 8(1), 236-273. https://www.jstor.org/stable/20720138.

Hackenberg, A. J. (2010). Students' Reasoning With Reversible Multiplicative Relationships. Cognition and Instruction, 28(4), 383-432. https://doi.org/10.1080/07370008.2010.511565.

Howe, R. (1998). The AMS and mathematics education: The revision of the "NCTM standards" Notices of the $A M S,(45(2), 243-247$.

Hudoyo. H. (1988). Mengajar Belajar Matematika (Teaching Learning Mathematics). (Jakarta: LPTK Ministry of Education and Culture). 
Kabael, Tangul \& Akin, Ayca. (2016). Between Pre-Service Mathematics Teachers' Quantitative Reasoning And Their Support For Quantitative Reasoning. Proc. ${ }^{13}$ th International Congress on Mathematical Education. Hamburg, 24-31.

Karim. N. (2007). Quantitative Reasoning Applications and Modelling in The Real World. (Zayed University). http://math.unipa.it/ grim/21_project/21_Charlotte_KarimPaperEdit.

Madison, B. L. (2003). The Many Faces of Quantitative Literacy. Quantitative Literacy: Why numeracy matters for schools and colleges, 3-6. http://www.gram.edu/sacs/qep/chapter\%205/5_22.

Malhotra, N.K. \& Birks, D.F. (2007). Marketing Research: An Research, $3^{\text {rd }}$ European Edition, Harlow. UK: Pearson Education

Mathematical Association of America (MAA). (2003). Guidelines for Programs and Departments in Undergraduate Mathematical Sciences. (Washinton, DC: Author).

Ministry of Education and Culture (Depdiknas). (2006). Permendiknas Nomer 22 Tahun 2006 tentang Standar Isi untuk Satuan Pendidikan Dasar dan Menengah (Minister of National Education Regulation Number 22 of 2006 concerning Content Standards for Primary and Secondary Education). (Units. Jakarta: BSNP).

Moore, K. C. (2014). Quantitative Reasoning and The Sine Function: The Case of Zac. Journal for Research in Mathematics Education, 45(1), 102-138. doi: 10.5951/jresematheduc.45.1.0102.

NCTM. (2000). Principles and Standards for School Mathematics. (Virginia: NCTM).

Ramful, A., \& Ho, S. Y. (2015). Quantitative Reasoning In Problem Solving. (Australian Primary Mathematics Classroom, 20(1), 15. https://files.eric.ed.gov/fulltext/EJ1093234.

Slavin, R. E. (2006). Educational Psychology: Theory and practic (8th Edition). (USA: Allyn Bacon).

Sroyer. A. (2013). Quantitative Reasoning in Solving Mathematical Problems. In Proc. of the National Mathematics and Mathematics Education Seminar. UNY, 56-60

Sumarmo. U. (2013). Berpikir dan Disposisi Matematik Serta Pembelajarannya (Mathematical Thinking and Disposition and Learning): Collection of Papers. Department of Mathematics Education, UPI, Bandung.

Sumarmo. U. (1987). Kemampuan Pemahaman dan Penalaran Matematika Siswa SMA dikaitkan dengan Kemampuan Penalaran Logik Siswa dan Beberapa Unsur Proses Belajar Mengajar (Students 'Mathematical Understanding and Reasoning Abilities are associated with Students' Logical Reasoning Abilities and Some Elements of the Teaching and Learning Process). doctoral diss., PPs UPI Bandung.

Thompson, P. W. (1993). Quantitative Reasoning, Complexity, and Additive Structures (Educational Studies İn Mathematics) 165-208. doi. 10.1007/BF01273861.

Urbina, S. (2004). Essentials of Psychological Testing. New Jersey: John Wiley \& Sons.

Weber, E., Ellis, A., Kulow, T., \& Ozgur, Z. (2014). Six principles for quantitative reasoning and modeling. (Mathematics Teacher, 108 (1), 24-30. doi:10.5951/mathteacher.108.1.0024. https://www.jstor.org/stable/10.5951/mathteacher.108.1.0024. 